\title{
Expression of Noradrenergic and Cholinergic Traits by Sympathetic Neurons Cultured without Serum ${ }^{1}$
}

\author{
EVE J. WOLINSKY, ${ }^{2}$ STORY C. LANDIS, AND PAUL H. PATTERSON \\ Department of Neurobiology, Harvard Medical School, Boston, Massachusetts 02115
}

\begin{abstract}
The ability to vary systematically the neuronal environment is one advantage afforded by the use of cell culture. Replacement of serum, a variable and undefined medium supplement, with known ingredients allows even greater control of culture conditions. We have studied biochemical and morphological properties related to neurotransmitter metabolism of rat sympathetic neurons cultured in a modified defined medium. Neuronal survival, ultrastructure, and expression of noradrenergic properties appear similar in serum-free and serum-supplemented cultures: small granular vesicles characteristic of norepinephrine storage were observed in both types of culture, and tyrosine hydroxylase activity, conversion of dopamine to norepinephrine, catecholamine production, and storage capacity are equivalent in serum-free and serum-containing cultures. Several of these properties were not exhibited at high levels in previous formulations of this defined medium. Acetylcholine production, however, was about 10-fold lower in serum-free compared to serum-supplemented cultures, consistent with the findings of lacovitti et al. (lacovitti, L., M. I. Johnson, T. H. Joh, and R. P. Bunge (1982) Neuroscience 7: 2225-2239). Acetylcholine production can be induced under serum-free conditions by a previously characterized cholinergic inducing factor from heart cell conditioned medium. This responsiveness to serum-free heart cell conditioned medium indicates that serum-free cultures retain plasticity with respect to transmitter status, despite expression of noradrenergic characteristics, unlike cultured neurons of which the noradrenergic transmitter status is maintained by chronic depolarization. Thus, sympathetic neurons survive, express numerous differentiated properties,
\end{abstract}

Received July 2, 1984; Revised October 5, 1984;

Accepted October 8, 1984

${ }^{1}$ We wish to thank Doreen McDowell for assistance with the cell culturing and John Fredieu for assistance with the electron microscopy. We also thank Dr. T. M. Jessell for helpful discussion of the manuscript. E. J. W. was a predoctoral trainee of the National Institute of General Medical Sciences. S. C. L. is an Established Investigator of the American Heart Association, supported, in part, by the Massachusetts Affiliate. P. H. P. was a Rita Allen Foundation Scholar and a McKnight Foundation Neuroscience Development Awardee. Support was also provided by grants from the National Institute of Neurological and Communicative Disorders and Stroke to P. H. P. and S. C. L.

${ }^{2}$ To whom correspondence should be sent at her present address: Department of Biology, Massachusetts Institute of Technology, Cambridge, MA 02139.

${ }^{3}$ Present address: Division of Biology, California Institute of Technology, Pasadena, CA 91125. and display a novel transmitter status under serum-free conditions.

Cellular differentiation is often regulated by both environmental signals and intrinsic information. To determine which developmental events are directed by internal programming fixed at earlier stages, and which are malleable to extrinsic influences, it is necessary to gain control of the cellular environment by using special techniques such as tissue culture. This has been a productive approach to studying environmental influences on neurotransmitter choice by rat sympathetic neurons (Patterson, 1978). Uncontrolled variables in the culture milieu, however, make analysis of the effects of molecules of interest more difficult and may even obscure relevant phenomena (e.g., Dibner and insel, 1981; Darfler et al., 1981). Serum is a common additive to culture medium. It contains both large (Barnes and Sato, 1980) and small (Ham, 1981) molecular weight molecules able to sustain numerous cell types in culture. Because the composition of serum is variable and complex, the identities and potency of many of these molecules are unknown. Replacement of serum with defined components (Barnes and Sato, 1980) has proven useful in providing better control of culture conditions and in studying the role of specific molecular requirements in cellular growth and differentiation. In order to better understand both the intrinsic properties of cultured sympathetic neurons and those which are modulated by aspects of the culture environment, such as serum, we have replaced serum with a modification of a defined medium formulated by Bottenstein and Sato (1979).

Defined serum-free media have been shown to sustain growth and differentiation of several nervous system-related cell types in primary culture: astrocytes (Morrison and DeVellis, 1981), oligodendrocytes (Raff et al., 1983), mesencephalic neurons (di Porzio et al., 1980), cerebellar neurons (Messer et al., 1981), fetal rat brain neurons (Ahmed et al., 1983), neural crest cells (Bader et al., 1983; Ziller et al., 1983), and cardiac muscle cells (Mohamed et al., 1983). Several groups have reported on the scrum-free culture of sympathetic and sensory neurons. Bottenstein et al. (1980) demonstrated short-term survival of a subpopulation of chick sensory neurons cultured in defined medium. Wakade et al. (1982) studied survival but not the differentiated characteristics of chick sensory and sympathetic neurons under serum-free conditions. A qualitative description of the ultrastructure of human fetal sympathetic neurons cultured without serum was provided by Zeevalk et al. (1982). Freschi (1982) cultured dissociated rat superior cervical ganglion in the absence of serum but did not eliminate the influence of non-neuronal cells from the cultures. lacovitti et al. (1982) provided a more complete characterization of serum-free cultures of rat sympathetic neurons free of non-neuronal cells. They reported that tyrosine hydroxylase (TH) activity, but not dopamine $\beta$-hydroxylase activity, choline acetyltransferase activity, or endogenous norepinephrine (NE) content attained levels comparable to those of serum-containing cultures. In addition, both vesicle-containing profiles and the dense-cored vesicles char- 
acteristic of catecholamine (CA) storage were noted to be less frequent than in serum-containing cultures. They concluded that some, but not all, aspects of the noradrenergic phenotype could develop under serum-free conditions, whereas no indications of cholinergic development were observed.

We report here the characterization of differentiated properties of sympathetic neurons maintained in defined medium using culture conditions somewhat different from those of previous investigators. Uncter lhese conditions, CA content and ultrastructure were comparable to those seen in serum-containing cultures. Some of the results reported here were reported briefly elsewhere (Wolinsky et al., 1983).

\section{Materials and Methods}

Cell culture. Single cell suspensions of newborn rat superior cervical ganglia were prepared using enzymatic dissociation as described by Wolinsky and Patterson (1983). An amount of cell suspension equivalent to that obtained from two ganglia (20,000 to 30,000 cells/ganglion) was plated in each 1-cm-diameter collagenized well cut into $35-\mathrm{mm}$-diameter culture dishes. Each culture dish contained $1.5 \mathrm{ml}$ of $\mathrm{L} 15 / \mathrm{CO}_{2}$ medium containing $5 \%$ rat serum (Hawrot and Patterson, 1979). This serum-containing medium was supplemented with $10 \mu \mathrm{M}$ cytosine-1- $\beta$-D-arabinoside (Sigma Chemcial Co.) to eliminate non-neuronal cells released during enzymatic treatment. After 12 to $36 \mathrm{hr}$ of incubation (generally, overnight) at $37^{\circ} \mathrm{C}$ in a $5 \% \mathrm{CO}_{2}$ atmosphere, neurons were sufficiently well attached to the culture substratum to tolerate a gentle changing of culture medium. As much serum-containing medium as possible was removed from the culture dishes without dislodging the young neurons and was replaced with serum-free L15N2 medium. L 15N2 medium consists of carbonate-buffered $\mathrm{L} 15 / \mathrm{CO}_{2}$ medium (Flow Laboratories) supplemented with glucose, glutamine, antibiotics, and vitamins (described by Hawrot and Patterson, 1979) and $1 \mu \mathrm{g} / \mathrm{ml}$ of 75 nerve growth factor (prepared as described by Bocchini and Angeletti, 1969) and a mixture of hormones and nutrients devised by Bottenstein and Sato (1979) to support serum-free culture of neuroblastoma cells: $100 \mu \mathrm{g} / \mathrm{ml}$ of transferrin (Sigma or Calbiochem); $5 \mu \mathrm{g} / \mathrm{ml}$ of bovine insulin, zinc salt (Sigma); $16 \mu \mathrm{g} / \mathrm{ml}$ of putrescine, free base (Sigma); $20 \mathrm{~nm}$ progesterone (Sigma); and $30 \mathrm{~nm}$ selenious acid. Stock solutions of these reagents were maintained as follows: $10 \mathrm{mg} / \mathrm{ml}$ of transferrin in phosphate-buffered serum (PBS), stored frozen; $2.5 \mathrm{mg} / \mathrm{ml}$ of insulin in $5 \mathrm{~mm} \mathrm{HCl}$, stored at $4^{\circ} \mathrm{C}$ (stable for 1 month); $1.6 \mathrm{mg} /$ $\mathrm{ml}$ of putrescine in PBS, stored at $4^{\circ} \mathrm{C} ; 20 \mu \mathrm{M}$ progesterone in absolute ethanol, stored at $4^{\circ} \mathrm{C}$; and $30 \mathrm{~nm}$ selenious acid in water, neutralized with $\mathrm{NaOH}$. One hundred or $200 \mathrm{ml}$ of $L 15 \mathrm{~N} 2$ were prepared at a time and used for 1 to 2 weeks with storage at $4^{\circ} \mathrm{C}$.

Non-neuronal cell proliferation in L15N2 medium was generally negligible if cytosine arabinoside treatment was applied as described (Wolinsky and Patterson, 1983) at the time of plating. However, if non-neuronal cells began to appear at later times in serum-free cultures, they were suppressed by overnight treatment with cytosine arabinoside. Unlike those in serum-supplemented cultures, neurons in L15N2 cultures do not survive continuous incubation in $10 \mu \mathrm{M}$ cytosine arabinoside for several days at a time. Cultures were maintained in L15N2 in the virtual absence of non-neuronal cells from about the third day of plating onward. Serum-free cultures were fed according to the same schedule as serum-containing culturos, three times per week, by removing $1 \mathrm{ml}$ of old medium and replacing it with $1 \mathrm{ml}$ of fresh medium.

All comparisons within one experiment were made between sister cultures. Cultures were used in experimenls between 2.5 and 4 weeks in vitro and usually contained 1000 to 3000 neurons/dish. Cultures maintained under chronic depolarizing conditions were fed medium to which an additional 20 $\mathrm{mM}$ of $\mathrm{KCl}$ was added in exchange for an equal amount of $\mathrm{NaCl}$ (Walicke et al., 1977). Serum-containing cultures were plated and maintained as described previously (Hawrot and Patterson 1979; Wolinsky and Patterson 1983).

Metabolic labeling of neurotransmitters. Isotopic incubation of living cultures with radiolabeled tyrosine and choline and high voltage electrophoretic separation of their metabolic products have been described previously (Mains and Patterson, 1973; Patterson and Chun, 1977). Isotopes were purchased from New England Nuclear: L-[ring 2,6- $\left.{ }^{3} \mathrm{H}\right]$ tyrosine, $37 \mathrm{Ci} / \mathrm{mmol}$, and [methyl$\left.{ }^{3} \mathrm{H}\right]$ choline chloride, $80 \mathrm{Ci} / \mathrm{mmol}$. Both serum-free and serum-containing cultures were incubated in labeling medium containing serum. Use of L15N2 medium for metabolic labeling does not affect neurotransmitter production by either culture type (data not shown).

Heart cell conditioned medium preparations. Serum-free cell conditioned medium (SFCM) was prepared by the method of Fukada (1980) using epidermal growth factor (EGF) prepared in our laboratory by Dr. K. Fukada according to the method of Savage and Cohen (1972). For some experiments SFCM was partially purified and 10 -fold concentrated by ammonium sulfate precipitation as described by Weber (1981). SFCM preparations were stored frozen in small aliquots and diluted appropriately with culture medium just prior to feeding.

TH assays. TH specific activity was assayed by the method of Hendry and Iversen (1971) with modifications previously described (Wolinsky and Patterson, 1983). Protein was measured using the bromosulfophthalein binding assay of Wallace and Partlow (1978) or microassay with a commercially prepared Bradford reagent (Bio-Rad) using bovine serum albumin as a standard.

$\left[{ }^{3} \mathrm{H}\right] N E$ uptake and release. Uptake and release of [ring-2,5, $\left.6-{ }^{3} \mathrm{H}\right] \mathrm{NE}(44.7$ $\mathrm{Ci} / \mathrm{mmol}$, New England Nuclear) was determined as described by Patterson et al. (1976). Cultures were incubated with $2.1 \mu \mathrm{Ci} / \mathrm{ml}$ of $\left[{ }^{3} \mathrm{H}\right] \mathrm{NE}$ and $25 \mu \mathrm{g} /$ $\mathrm{ml}$ of ascorbic acid in culture medium without bicarbonate at $37^{\circ} \mathrm{C}$ in an air atmosphere for $1 / 2 \mathrm{hr}$. The cultures were then rinsed five times with nondepolarizing buffered salt solution $\left(3 \mathrm{mM} \mathrm{CaCl}_{2}, 5 \mathrm{~mm} \mathrm{KCl}, 140 \mathrm{mM} \mathrm{NaCl}, 15\right.$ mM HEPES, buffered to $\mathrm{pH} 7.4$ with Tris, as described by Sweadner, 1983). The cultures were then incubated at $37^{\circ} \mathrm{C}$ in either nondepolarizing or depolarizing (an additional $49 \mathrm{~mm} \mathrm{KCl}$ replacing an equal amount of $\mathrm{NaCl}$ ) buffered salt solution, and aliquots of the bath were removed periodically for scintillation counting. At the end of the experiment, cultures were lysed with $1 \%$ SDS, and the remaining intracellular radioactivity was determined by scintillation counting of an aliquot of this extract.

Electron microscopy. In order to examine general neuronal ultrastructure, cultures were fixed in $3 \%$ glutaraldehyde in $0.12 \mathrm{M}$ phosphate buffer, $\mathrm{pH} 7.3$, directly after removal of the culture medium, at room temperature for $20 \mathrm{~min}$, and then overnight at $4^{\circ} \mathrm{C}$. The cultures were rinsed with phosphate buffer, postfixed with $1.3 \%$ osmium tetroxide in phosphate buffer for $20 \mathrm{~min}$, stained en bloc with $1 \%$ uranyl acetate in $0.05 \mathrm{M}$ acetate buffer, $\mathrm{pH} 5$, dehydrated with ethanol, and embedded in Epon 812. Thin sections were cut parallel to the collagen substrate, stained with lead citrate, and examined with a Phillips 400 electron microscope. To examine vesicular stores of endogenous NE (Richardson, 1966; Hokfelt, 1968), cultures were fixed with $3.5 \%$ potassium permanganate in either 0.1 ? $\mathrm{M}$ phosphate buffer or in distilled water for 30 min at $4^{\circ} \mathrm{C}$. The cultures were then rinsed thoroughly with cold acetate buffer, $\mathrm{pH} 5$, stained en bloc with uranyl acetate, dehydrated, and embedded. To examinc the ability of the neurons to take up and store exogenous CA in vesicles, cultures were incubated at $37^{\circ} \mathrm{C}$ in growth medium containing 10 $\mu \mathrm{M}$ 5-hydroxydopamine, an NE congener (Tranzer and Thoenen, 1967), and then fixed wilh pernanganate. For quantitative studies, terminals and varicosities were randomly selected and photographed at $\times 19,500$. Small granular and synaptic vesicles were counted on micrographs at a final magnification of $\times 48,500$.

Preparation of extracellular matrix from Bovine endothelial cells. Bovine endothelial cells were obtained from the laboratory of D. Gospodarowicz (University of California at San Francisco Medical Center). Extracellular matrixcoated dishes were prepared by a modification of the method of Gospodarowicz et al. (1980). Bovine endothelial cells were plated at about one-third confluent density into collagenized culture wells and maintained in $\mathrm{L} 15 / \mathrm{CO}_{2}$ medium supplemented with $5 \%$ calf serum (Gibco), $10 \%$ fetal calf serum (Gibco), and $1 \mu \mathrm{g} / \mathrm{ml}$ of fibroblast growth factor (Collaborative Research), until 3 days after the cells attained confluence. These were then lysed at room temperature with $20 \mathrm{~mm}$ ammonium hydroxide for $15 \mathrm{~min}$. The lysed cultures were washed three times with calcium, magnesium-containing PBS and used immediately for plating neurons.

\section{Results}

Survival and transmitter production. Survival and transmitter production are useful indices of the adequacy of the culture environment to support neuronal function. The survival and extent of CA production ol serum-containing and serum-free cultures are compared in Figure 1. The cell counts illustrated in Figure $1 \mathrm{~A}$ indicate that both kinds of cultures contain similar numbers of neurons. Serum-free and serum-containing cultures contain similar amounts of protein as well, about $5 \mathrm{ng} /$ neuron for 3-week-old cultures. CA productionthe sum of NE and dopamine (DA) - measured by metabolic labeling is also similar (Fig. $1 B$ ). Under both culture conditions, more than twice as much NE is produced as DA (Fig. 1C). This suggests that conversion of DA to NE by the enzyme dopamine $\beta$-hydroxylase occurs to a similar extent in both types of cultures. Blockade of loading of CA storage vesicles with reserpine (Iversen, 1967; Patterson et al., 1976) inhibits CA accumulation by both serum-containing 

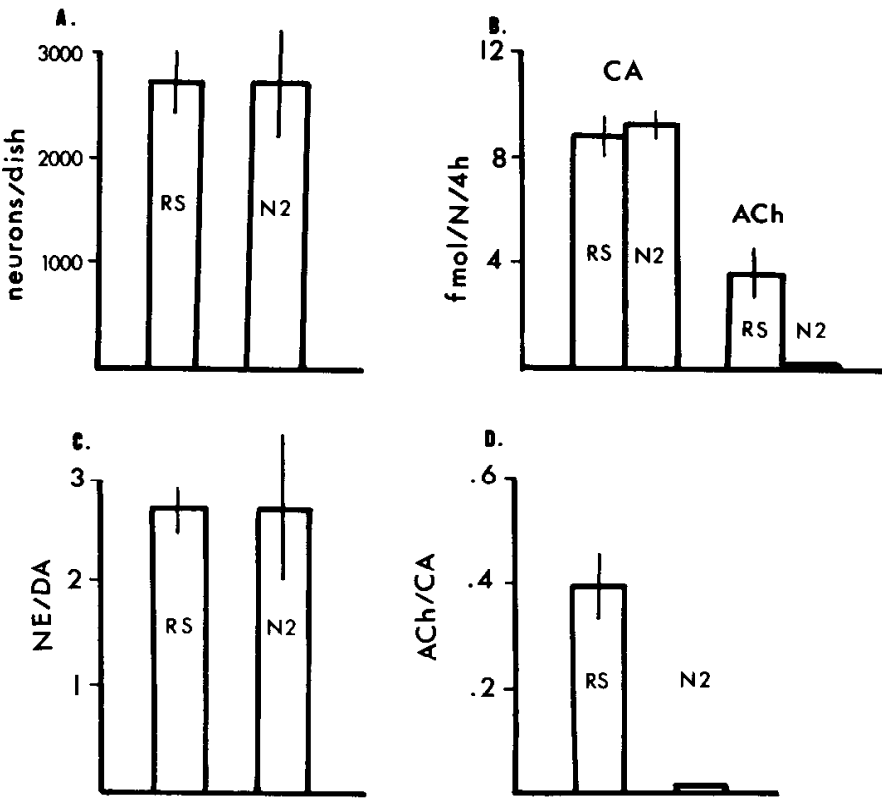

Figure 1. Survival, and $\mathrm{CA}$ and $\mathrm{ACh}$ production. A displays the number (mean \pm SE for three cultures) of neurons observed under phase contrast optics per culture. RS refers to serum-containing cultures; $N 2$ refers to cultures maintained in L1bN2 medium. $B$ indicates CA (sum of NE and DA production) and $A C h$ production during metabolic labeling in femtomoles per neuron (mean $\pm \mathrm{SE}$ for three cultures). $C$ shows the relative amounts of NE and DA produced during metabolic labeling as the ratio of NE to DA (mean $\pm \mathrm{SE}$ for three cultures). $D$ shows the relative amounts of $\mathrm{CA}$ and $\mathrm{ACh}$ produced during metabolic labeling as the ratio of ACh to CA (mean \pm SE for three cultures).

TABLE ।

Effect of reserpine on neurotransmitter production

Transmitter production was determined during metabolic labeling. Values indicated are mean \pm range. "Serum-tree" $\left(^{*}\right)$ cultures in this experiment were maintained in culture medium supplemented with only insulin $(5 \mu \mathrm{g} / \mathrm{ml})$ and transferrin $(100 \mu \mathrm{g} / \mathrm{ml})$, as described in Table $V$ and its legend. Reserpine phosphate (Ciba) was dissolved as much as possible in PBS to prepare a 1 $\mathrm{mM}$ stock solution, which was diluted in medium to obtain a nominal concentration of $2 \mu \mathrm{M}$.

\begin{tabular}{lcccc}
\hline \multicolumn{1}{c}{ Culture Type } & $\begin{array}{c}\text { Reserpine } \\
(2 \mu \mathrm{M})\end{array}$ & $\begin{array}{c}\text { Picomoles of } \\
\text { CA per Dish }\end{array}$ & $\begin{array}{c}\text { Picomoles of } \\
\text { ACh per Dish }\end{array}$ & $\begin{array}{c}\text { No. of } \\
\text { Cultures per } \\
\text { Determination }\end{array}$ \\
\hline Serum-free $^{*}$ & - & $12.80 \pm 0.77$ & $0.08 \pm 0.06$ & 2 \\
Serum-free $^{\star}$ & + & $0.15 \pm 0.02$ & $0.06 \pm 0.01$ & 2 \\
Rat serum $(2.5 \%)$ & - & 15.00 & 0.41 & 1 \\
Rat serum $(2.5 \%)$ & + & 0.06 & 0.42 & 1 \\
\hline
\end{tabular}

and serum-free cultures (Table I). Taken together, these data indicate that synthesis and storage of CA are similar in both types of cultures.

The two types of cultures differ, however, in production of metabolically labeled acetylcholine (ACh). Serum-free cultures produced less than $3 \%$ as much $A C h$ as serum-containing cultures (Fig. 1B). This difference is reflected in the ratios of $A C h$ to $C A$ production in the two types of cultures (Fig. 1D). Conventional serum-containing cultures, so-called dual-function neurons (Furshpan et al., 1976; lacovitti et al., 1981; Wolinsky and Patterson, 1983), generally produce both transmitters at levels with the same order of magnitude. In contrast, the ratio of ACh to CA production in serum-free cultures is quite low (Fig. 1D). This low ratio is similar to that of serumcontaining cultures maintained in the noradrenergic state by chronic depolarization in medium with elevated potassium levels (Walicke et al., 1977). Thus, the transmitter status of serum-free and serumcontaining cultures are different.

Lack of ACh production by neurons cultured with L15N2 medium (Fig. 1B) could be due either to a direct suppression of $\mathrm{ACh}$ production by constituents of N2 medium (insulin, transferrin, putrescine, selenium, and progesterone) or to the absence of serum factors which might be required to support or induce ACh production. The first possibility can be tested by addition of N2 constituents to serum-containing medium. As shown in Figure 2, N2 constituents do not suppress $A C h$ production when combined with rat serum. It therefore seems likely that lack of ACh production in serum-free cultures is related to the absence of serum rather than to the presence of the ingredients used to replace it. The implication that rat serum is the agent responsible for the modest cholinergic development exhibited by dual-function cultures is investigated in the following article (Wolinsky and Patterson, 1985a).

Induction of ACh production in serum-free cultures. ACh production by serum-containing cultures can be greatly stirmulated by addition of medium conditioned by cultured heart cells (Patterson and Chun, 1977). Heart cell conditioned medium can be prepared without serum if appropriate hormones are added (Fukada, 1980). Such a serum-free preparation was used to determine whether serum-free cultures were responsive to cholinergic induction. The response of neurons maintained in L15N2 medium to SFCM is shown in Table II (see also Table IV). In this experiment, both serumfree and serum-containing cultures responded to the addition of SFCM with increases of ACh production of 50- and 20-fold, respectively, with the result that both types of cultures attained similar levels of ACh production. These data indicate that serum-free cultures can develop the capacity for ACh production in response to heart cell conditioned medium.

SFCM contains many other products secreted by heart cells in addition to the protein associated with cholinergic inducing activity (Fukada, 1980). The possibility that the cholinergic induction ob-

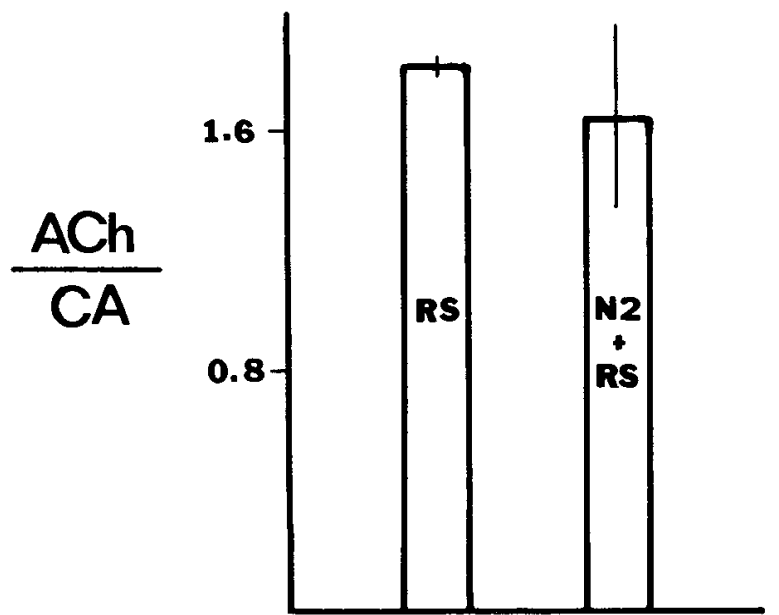

Figure 2. Lack of effect of N2 ingredients on ACh to CA ratio. The ratio of $A C h$ to $C A$ production during metabolic labeling is compared for serumcontaining culturcs with (N2 + RS) and without (RS) N2 ingredients added (mean \pm SE determined for four N2 + RS and two RS cultures).

TABLE ॥

Induction of ACh production in serum-free cultures by SFCM

Transmitter production during metabolic labeling is indicated in femtomoles per neuron. Values shown are mean $\pm \mathrm{SE}$, determined from the number of cultures shown in column 4. "RS" and "N2" indicate serum-containing and serum-free cultures, respectively. "SFCM" indicates cultures maintained in serum-free heart cell conditioned medium diluted $50 \%$ with fresh culture medium.

\begin{tabular}{lcrc}
\hline Culture Type & $\begin{array}{r}\text { Femtomoles of } \\
\text { CA per Neuron }\end{array}$ & $\begin{array}{r}\text { Femtomoles of } \\
\text { ACh per Neuron }\end{array}$ & $\begin{array}{c}\text { No. of } \\
\text { Cultures }\end{array}$ \\
\hline RS & $5.35 \pm 1.81$ & $0.48 \pm 0.16$ & 4 \\
RS + SFCM & $4.90 \pm 0.73$ & $12.60 \pm 4.41$ & 5 \\
N2 & $5.56 \pm 0.61$ & $0.19 \pm 0.11$ & 6 \\
N2 + SFCM & $2.14 \pm 1.06$ & $8.90 \pm 2.30$ & 3 \\
\hline
\end{tabular}


served in serum-free cultures is due to effects of these other molecules has been tested by observing the effect of cholinergic inducing factor purified from SFCM on CM-cellulose by the method of Weber (1981; gift of Dr. R. Pittman), and by observing the effect of SFCM prepared without the hormone EGF, which is essential for release of cholinergic inducing activity from heart cells (Fukada, 1980). Partially purified SFCM factor is able to stimulate ACh production by serum-free cultures to the same extent as serum-containing cultures (data nol shown). EGF-deficient SFCM, which contains other heart cell-secreted products, but little cholinergic inducing factor, does not stimulate ACh production by serum-free cultures (data not shown). These observations argue against the possibility that active, EGF-containing SFCM nonspecifically enhances ACh production by supplying trophic support absent from serum-free medium.

TH activity. The CA production levels discussed above were determined by a metabolic labeling technique which measures net CA content, dependent on processes of CA breakdown, release, and reuptake, as well as synthesis (Patterson and Chun, 1977). To obtain a measure of CA biosynthetic capacity in isolation from these other processes, the activity of the enzyme $\mathrm{TH}_{\text {, the first and rate- }}$ limiting enzyme required to convert tyrosine to $\mathrm{DA}$ and $\mathrm{NE}$, was assayed in culture extracts. As reported previously for serum-containing cultures (Swerts et al., 1983; Wolinsky and Patterson, 1983), $\mathrm{TH}$ specific activity was found to correlate with levels of CA production measured by metabolic labeling (Fig. 3): serum-free and serumcontaining cultures have comparable levels of both TH activity and CA production.

$\mathrm{TH}$ levels and $\mathrm{CA}$ production in serum-containing cultures are inversely related to the level of ACh production (Patterson and Chun, 1977; Fukada, 1980; Wolinsky and Patterson, 1983). As shown in Figure 3 , serum-free cultures are also able to respond to large doses of cholinergic inducing factor with reduction of CA production (see also Table II) and TH activity levels.

CA uptake and release. CA uptake and storage capacity and spontaneous release rate also contribute to the CA production levels

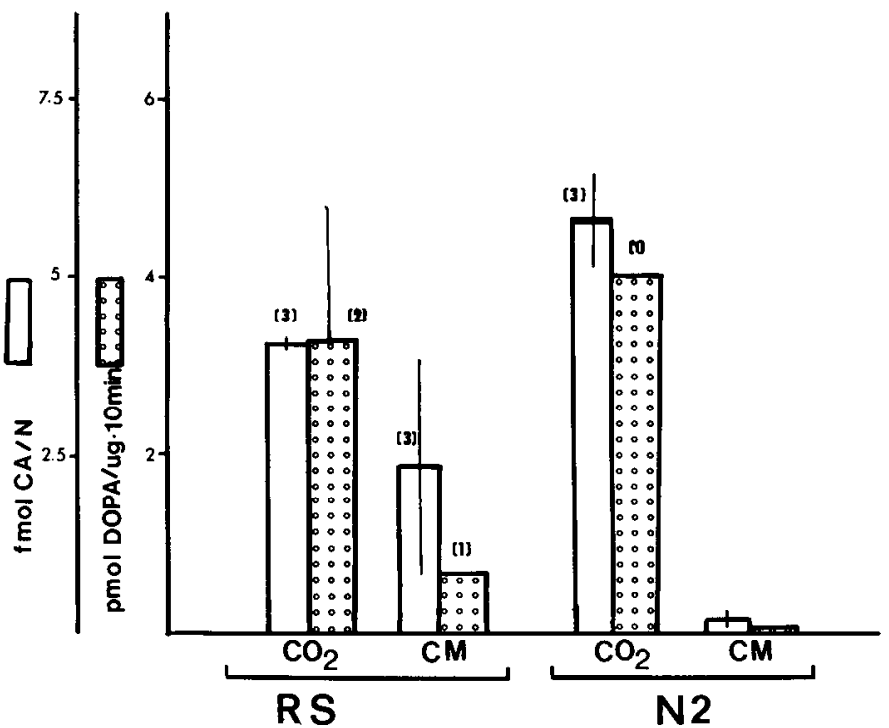

Figure 3. TH specific activity and CA production. The open bars indicate CA production during metabolic labeling in femtomoles per neuron. The speckled bars indicate specific activity of $\mathrm{TH}$ as picomoles of dihydroxyphenylalanine synthesized per microgram of protein during a 10 -min incu bation at $37^{\circ} \mathrm{C}$. RS and $N 2$ indicate cultures maintained in serum-containing and serum-free medium, respectively. $C M$ indicates that 10 -fold concentrated SFCM was added to the cultures at a concentration equivalent to $500 \%$ of preconcentration activity. $\mathrm{CO}_{2}$ indicates cultures grown without SFCM (values shown are mean \pm SE). The number of determinations for each average is indicated in brackets above each bar. (Serum data were published previously (Wolinsky and Patterson1983).) measured by metabolic labeling. These factors were compared for serum-free and serum-containing cultures by determining the amount of radiolabeled NE taken up by neurons from the culture medium and amounts subsequently released at various times into fresh medium. Both types of cultures accumulated similar amounts of $\left[{ }^{3} \mathrm{H}\right]$ NE during a half-hour incubation: $1.5 \mathrm{fmol} /$ neuron by serum-free cultures and $1.3 \mathrm{fmol} /$ neuron for serum-containing cultures. This results suggests that CA uptake and storage capacity are similar in both types of cultures.

Both spontaneous and depolarization-dependent CA release from serum-containing cultures have been studied (Patterson et al., 1976). The gradual diminution of the amount of radioactivity within neurons in nondepolarizing medium following loading with [ $\left.{ }^{3} \mathrm{H}\right] \mathrm{NE}$ is due to metabolic turnover and spontaneous release. A plot of the radioactivity remaining within the neurons at various times after preincubation with $\left[{ }^{3} \mathrm{H}\right] \mathrm{NE}$ versus time is shown in Figure 4 . The spontaneous release rate is similar for both serum-free and serum-containing cultures (Fig. 4). When the cultures are depolarized with medium containing elevated potassium, loss of radioactivity from cells is accelerated (Fig. 4). Depolarization-mediated transmitter release from serum-containing cultures has been demonstrated to share many features of release of CA from noradrenergic varicosities in vivo (Patterson et al., 1976). These stimulated release rates are also similar for both types of cultures. Taken together, the above data indicate that NE uptake, storage, and synaptic release have similar extent and time course in both serum-containing and serum-free cultures.

Morphology. Phase contrast micrographs of serum-free and serum-containing cultures are shown in Figure 5 . In many platings it was possible to distinguish serum-free and serum-containing cultures on the basis of the degree of bundling of neuronal processes. The neurites of serum-free cultures tended to fasciculate less than those of conventional cultures. The fiber bundles in such cultures were generally thinner and formed more extensive ramifications than in serum-containing cultures, conferring a distinctively spider web type of appearance. In addition, as noted by others (lacovitti et al., 1982), some serum-free platings contained a number of neurons with eccentrically placed nuclei. This feature varied considerably in extent between different platings.

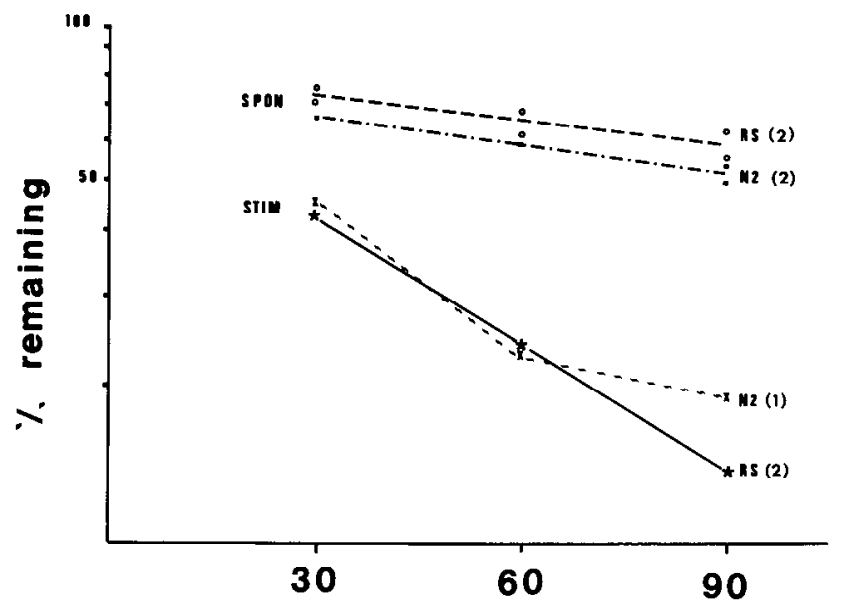

\section{m in}

Figure 4. Spontaneous and potassium-stimulated release of stored $\left[{ }^{3} \mathrm{H}\right]$ $N E$. The amount of [ $\left.{ }^{3} \mathrm{H}\right] \mathrm{NE}$ remaining in cultures is plotted semilogarithmically versus time after termination of isotope loading. At percentage remaining, " $100 \%$ remaining" represents the amount of radioactivity stored within neurons at the start of the release period. RS and N2 indicate serum-containing and serum-free cultures, respectively. SPON refers to release of tritium in nondepolarizing buffered salt solution; STIM refers to tritium release in the presence of $54 \mathrm{~mm}$ potassium ion. The numbers of cultures assayed for points shown are indicated in parentheses. 

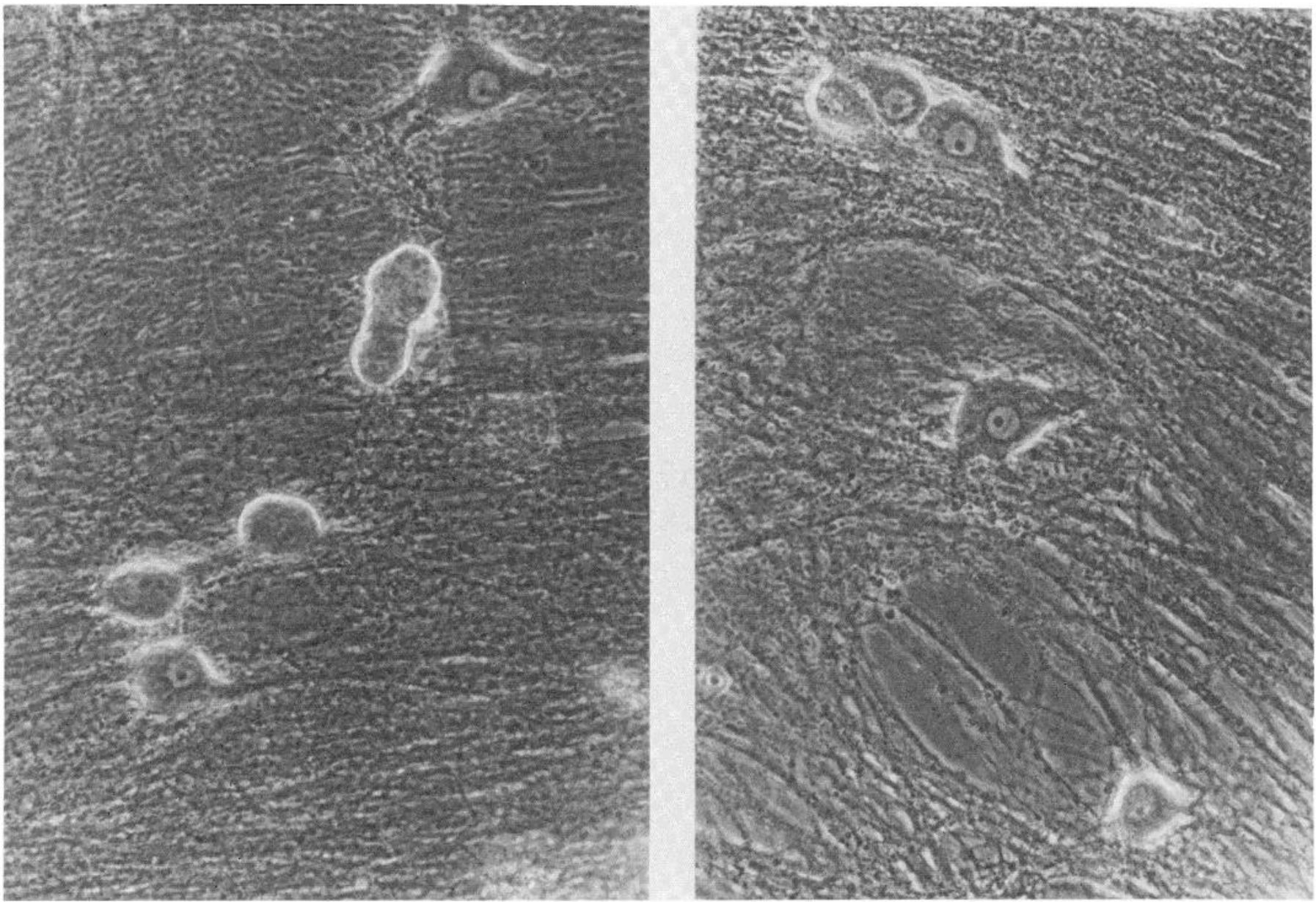

Figure 5. Comparison of light microscopic morphology of serum-free and serum-containing cultures. Phase micrographs of neurons maintained for 3 weeks in medium supplemented with $2.5 \%$ rat serum (left) or insulin $(5 \mu \mathrm{g} / \mathrm{ml})$ and transferrin $(100 \mu \mathrm{g} / \mathrm{ml})$ in the absence of serum (right).

Electron micrographs of aldehyde osmium-fixed material are shown in Figure 6. The ultrastructure of neurons maintained in serumfree medium was similar to that previously described for conventionally cultured neurons. The neuronal cell bodies contain profuse rough endoplasmic reticulum, prominent Golgi apparatus, and largely euchromatic nuclei. Vesicles containing varicosities are abundant along the neuronal processes. Morphologically specialized synapses characterized by pre- and postsynaptic densities, clear vesicles, and vesicles with dense cores and mitochondria are frequently observed. Two minor ultrastructural differences were noted between neurons grown under the two conditions. The cell bodies of serum-free neurons often contained many lysosomes and had more numerous microvillus extensions.

Potassium permanganate fixation (Richardson, 1966; Hokfelt, 1968) was used to localize stores of CA in synaptic vesicles as dense cores. Synapses and varicosities contained many small granular vesicles (Fig. 7). Two types of experiments were performed with this technique. The frequency of CA-containing vesicles was determined by counting small granular vesicles and clear vesicles in varicosities and terminals. In addition, the ability of cultures to take up and store exogenous CA in synaptic vesicles was assessed for cultures fixed with permanganate with and without preincubation with 5-hydroxydopamine (5-OHDA).

Small granular vesicle frequency distribution histograms for the first type of experiment are shown in Figure 8. The mean percentage of small granular vesicles per terminal for serum-containing and serum-free cultures were $40 \pm 4 \%$ and $23 \pm 2 \%$, respectively. In addition, the range of small granular vesicle frequencies in the serumfree culture was narrower and had a lower upper limit than that of the serum-containing culture. The ratio of $\mathrm{ACh}$ to $\mathrm{CA}$ production measured in sister cultures was $1.05 \pm 0.06$ for serum-containing cultures and $0.13 \pm 0.04$ for serum-free cultures $(n=3)$. The broad spread of the histogram for the serum-containing culture (Fig. $8 A$ ) is characteristic of dual-function cultures (Landis, 1980). A second experiment performed on a different plating (histogram not shown) showed a similar 2 -fold difference in small granular vesicle frequency between serum-containing and serum-free cultures. This result is surprising, since the biochemical studies described above indicate no discrepancies between serum-free and serum-containing cultures in the aspects of CA metabolism tested. The biochemically determined transmitter status of serum-free cultures is noradrenergic, like that of serum-containing, chronically depolarized cultures, (Walicke et al., 1977), which have a small granular vesicle frequency of $80 \%$ (Landis, 1980). However, the percentage of small granular vesicles in serum-free cultures is almost 4-fold lower. Possible explanations for this finding are considered under "Discussion."

Serum-containing cultures have been demonstrated previously to be able to incorporate exogenous 5-OHDA into dense-cored vesicles (Landis, 1980). Serum-free cultures also have this capacity. In a different plating from that analyzed above, small granular vesicle frequency was compared in serum-free cultures that had or had not been preincubated with $10 \mu \mathrm{M} 5-\mathrm{OHDA}$ prior to fixation with permanganate. Figure $7, b$ and $c$, compares terminals from such a pair of serum-free cultures. It is apparent that preincubation with 5-OHDA resulted in formation of dense cores in a greater proportion of vesicles.

Comparison with noradrenergic cultures maintained by chronic depolarization. Serum-containing cultures with noradrenergic trans- 


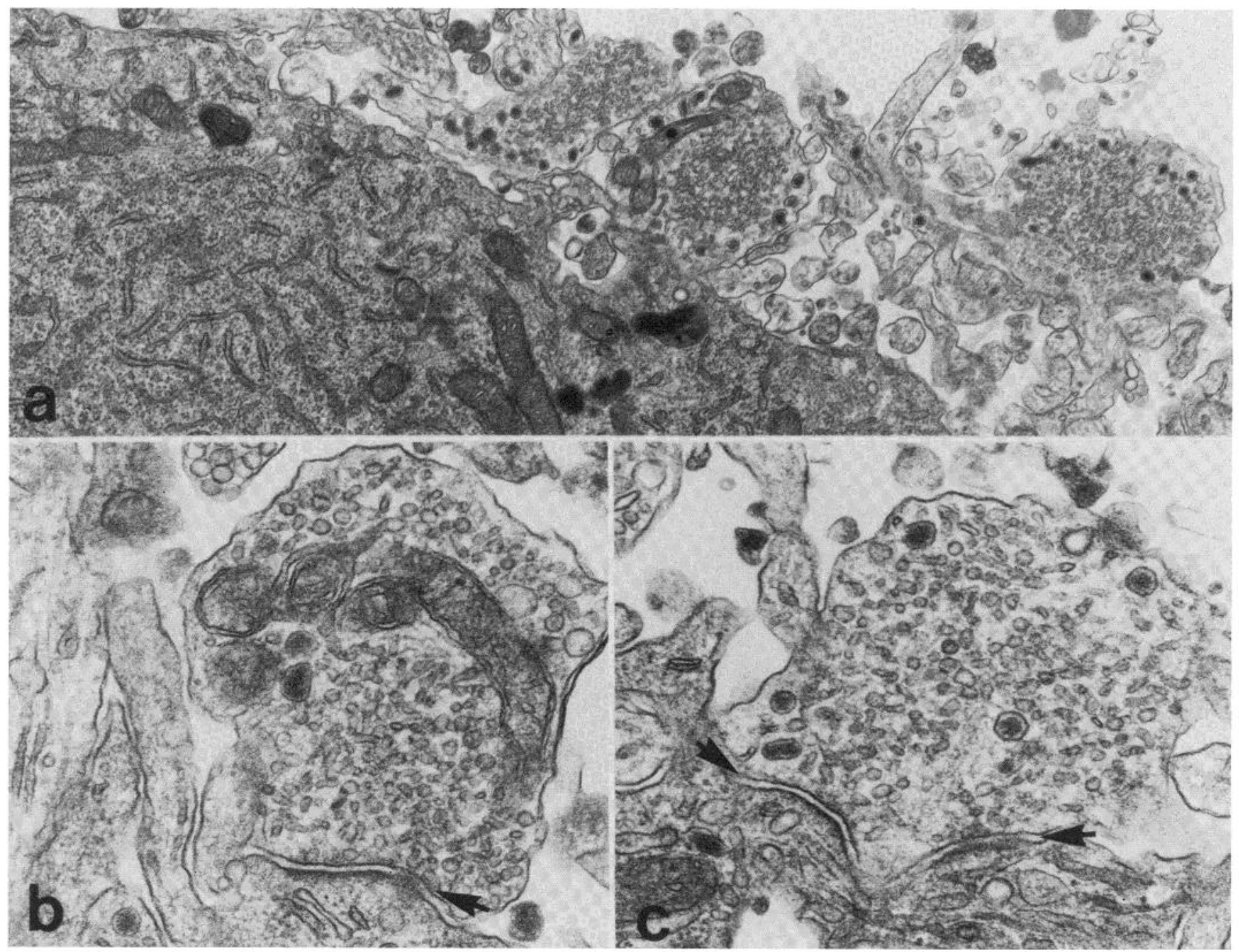

Figure 6. Ultrastructure of serum-containing cultures. Glutaraldehyde-fixed cultures were processed for electron microscopy as described under "Materials and Methods." a shows a portion of a neuron cell body and neurites passing nearby. b and c show varicosities with synaptic specializations (arrows).

mitter status can be produced by maintaining the neurons in medium containing elevated potassium levels (Walicke et al., 1977; Walicke and Patterson, $1981 \mathrm{a}, \mathrm{b})$. The ratio of ACh to CA production in such cultures is very low, similar to that of serum-free cultures. The effect of high potassium medium on serum-containing cultures has been well characterized: the capacity to produce ACh fails to develop; CA production capacity exhibits a significant, although variable increase; and responsiveness to cholinergic induction by heart cell conditioned medium is reduced substantially (Walicke et al., 1977). Since serum-containing, chronically depolarized cultures and serum-free cultures share the characteristic of producing a preponderance of $\mathrm{CA}$ and almost no $\mathrm{ACh}$, it is of interest to determine whether serum-free cultures share the other features of chronically depolarized serum-containing cultures and, if not, whether chronic depolarization can induce these characteristics under serum-free conditions.

No difference was observed in transmitter production between serum-free cultures grown with and without elevated potassium in about half of the platings examined. However, in other experiments, such as that shown in Table III, with higher production of ACh under serum-free conditions, an additional effect of high potassium can be discerned. In this experiment (Table III), high potassium concentration in medium without serum abolished the small but significant production of ACh exhibited by serum-free cultures maintained without chronic depolarization. Chronic depolarization of serum-free cultures resulted in both suppression of the small amount of $A C h$ production exhibited by nondepolarized cultures and elevation of CA production. These effects of chronic depolarization are similar in magnitude for both the serum-free and serum-containing cultures.

The effect of heart cell conditioned medium is reduced when it is administered in high potassium medium or when cultures initially maintained in high potassium medium are switched to medium mixed with heart cell conditioned medium (Walicke et al., 1977). Serumfree cultures, however, are able to respond to heart cell conditioned medium to the same extent as nondepolarized serum-containing cultures (Table IV). When high potassium is simultaneously administered with SFCM under both serum-containing and serum-free conditions, the effect of SFCM is reduced (Table IV). Thus, the refractoriness to SFCM treatment characteristic of chronically depolarized cultures is not a concomitant feature of the noradrenergic transmitter status of serum-free cultures. However, serum-free cultures respond to chronic depolarization by losing their susceptibility to the cholinergic inducing activity of heart cell conditioned medium.

Another paradigm used to investigate the effect of chronic depolarization on response to heart cell conditioned medium is to grow neurons for an initial period in the absence of SFCM and then to administer SFCM during a later period in culture (Walicke et al., 1977). With this protocol, the antagonistic effect of chronic depolarization on response to SFCM is more pronounced. The response of serum-containing, nondepolarized cultures to late administration of 


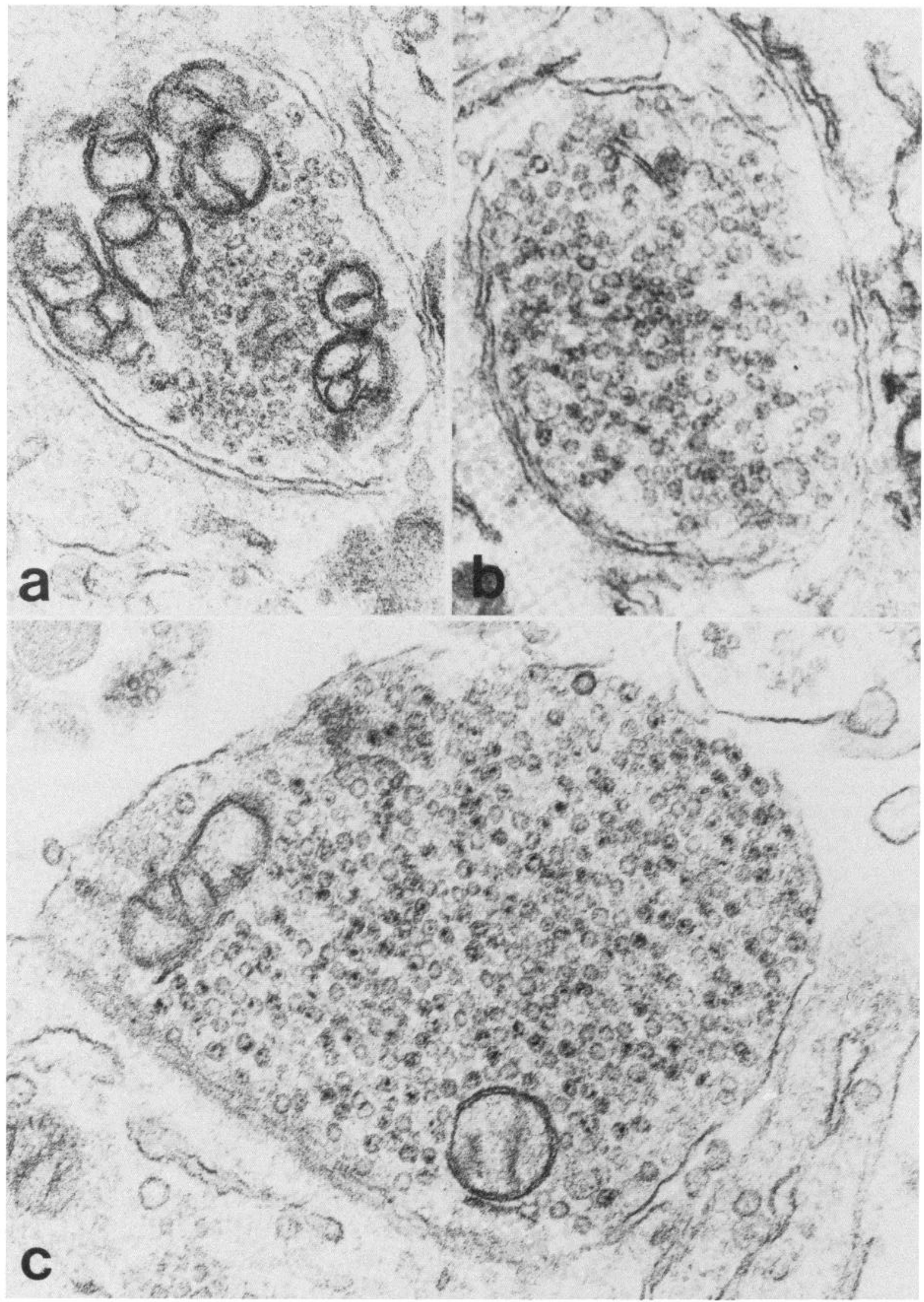

Figure 7. CA storage visualized by permanganate fixation. Processing of cultures with potassium permanganate treatment was as described under "Materials and Methods." a shows a terminal from a serum-supplemented culture fixed without preincubation with 5-OHDA. $b$ and $c$ show terminals from serum-free cultures with $(c)$ and without $(b)$ preincubation with 5-OHDA. 

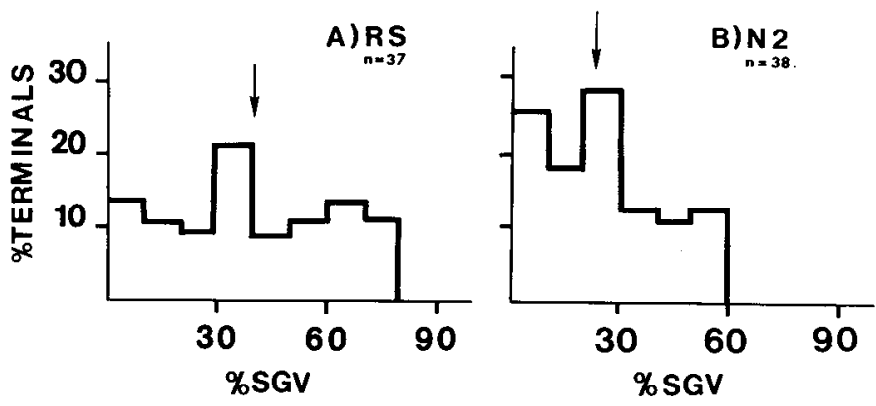

Figure 8. Small granular vesicle frequency histograms. The percentages of terminals containing the indicated percentages of small granular vesicles (SGV) are plotted against each other. The first bin is from 1 to $10 \%$ small granular vesicles per terminal. One serum-containing and one serum-free culture were fixed with potassium permanganate as described under "Materials and Methods" after 30 days in vitro. The number of terminals examined in random fields of each culture is indicated as $n$. Means are indicated by arrows.

TABLE III

Effect of elevated potassium on transmitter production

Transmitter production during metabolic labeling is indicated in femtomoles per neuron. Values shown are mean $\pm S E$, determined from the number of cultures shown in column 5. "RS" and "N2" indicate serum-containing and serum-free cultures, respectively. " $\mathrm{K}+$ " indicates cultures chronically depolarized with culture medium containing $20 \mathrm{mM} \mathrm{KCl}$.

\begin{tabular}{lrccc}
\hline Culture Type & $\begin{array}{r}\text { Femtomoles of } \\
\text { CA per Neuron }\end{array}$ & $\begin{array}{c}\text { Femtomoles of } \\
\text { ACh per Neuron }\end{array}$ & ACh/CA & $\begin{array}{c}\text { No. of } \\
\text { Cultures }\end{array}$ \\
\hline N2 & $8.73 \pm 1.49$ & $0.21 \pm 0.05$ & $0.024 \pm 0.005$ & 3 \\
N2K & $10.38 \pm 0.39$ & $0.02 \pm 0.0$ & $0.002 \pm 0$ & 3 \\
RS & $8.44 \pm 0.76$ & $6.21 \pm 1.21$ & $0.75 \pm 0.17$ & 3 \\
RSK $^{+}$ & $13.76 \pm 2.00$ & $<0.01$ & $<0.001$ & 3 \\
\hline
\end{tabular}

\section{TABLE IV}

ACh/CA ratio of cultures grown with or without serum, SFCM, and high $\mathrm{K}^{+}$

The medium in which cultures were maintained during the first 10 days in culture is indicated in column 1. "RS" indicates serum-containing medium, "N2" indicates serum-free medium, " $\mathrm{K}^{+"}$ indicates medium with potassium ion elevated to $23 \mathrm{mM}$ and " $\mathrm{CM}$ " indicates medium supplemented with 10-fold concentrated SFCM to the equivalent of $50 \%$ of its preconcentration activity. Column 2 shows the medium in which cultures were maintained during the subsequent 12 days of culture. After this period, the ratio of $\mathrm{ACh}$ to $\mathrm{CA}$ production, shown in column 3, was determined by metabolic labeling. The values indicated are mean $\pm S E$, determined for the number of cultures shown in column 4.

\begin{tabular}{llcc}
\hline $\begin{array}{c}\text { First } \\
\text { 10 Days }\end{array}$ & \multicolumn{1}{c}{$\begin{array}{c}\text { Next } \\
\text { 12 Days }\end{array}$} & ACh/CA & $\begin{array}{c}\text { No. of } \\
\text { Cultures }\end{array}$ \\
\hline $\mathrm{RS}$ & $\mathrm{RS}$ & $0.87 \pm 0.12$ & 3 \\
$\mathrm{RS}$ & $\mathrm{RS}+\mathrm{CM}$ & $2.43 \pm 0.11$ & 3 \\
$\mathrm{RS}+\mathrm{CM}$ & $\mathrm{RS}+\mathrm{CM}$ & $4.40 \pm 0.40$ & 2 \\
$\mathrm{~N} 2$ & $\mathrm{~N} 2$ & $0.15 \pm 0.05$ & 3 \\
$\mathrm{~N} 2$ & $\mathrm{~N} 2+\mathrm{CM}$ & $0.35 \pm 0.06$ & 2 \\
$\mathrm{~N} 2+\mathrm{CM}$ & $\mathrm{N} 2+\mathrm{CM}$ & $4.82 \pm 0.28$ & 3 \\
$\mathrm{RSK}^{+}$ & $\mathrm{RSK}^{+}$ & $0.20 \pm 0.14$ & 3 \\
$\mathrm{RSK}^{+}$ & $\mathrm{RSK}^{+}+\mathrm{CM}$ & $0.36 \pm 0.07$ & 3 \\
$\mathrm{RSK}^{+}+\mathrm{CM}$ & $\mathrm{RSK}^{+}+\mathrm{CM}$ & $2.21 \pm 0.21$ & 3 \\
$\mathrm{~N}^{+} \mathrm{K}^{+}$ & $\mathrm{N} 2 \mathrm{~K}^{+}$ & $0.05 \pm 0.02$ & 3 \\
$\mathrm{~N}^{+} \mathrm{K}^{+}$ & $\mathrm{N}^{+} \mathrm{K}^{+}+\mathrm{CM}$ & $0.02 \pm 0.01$ & 3 \\
${\mathrm{~N} 2 \mathrm{~K}^{+}+\mathrm{CM}}^{\mathrm{N} 2 \mathrm{~K}^{+}+\mathrm{CM}}$ & $1.71 \pm 0.33$ & 3 \\
\hline
\end{tabular}

SFCM is smaller than their response to SFCM treatment during the full culture period (Table IV). However, the response of serumcontaining, chronically depolarized cultures to late-applied SFCM is insignificant. This is a more complete antagonism of the effect of SFCM by high potassium than that obtained by applying SFCM throughout the culture period concomitant with chronic depolarization, which only reduced the response to SFCM 2-fold (Table IV). When cultures initially grown in serum-free medium only are switched to serum-free medium supplemented with SFCM, they respond poorly to the late-applied cholinergic stimulus. In this experimenta situation, the serum-free cultures behave similarly to serum-containing, chronically depolarized cultures.

Role of N2 constituents and culture substrate in neuronal survival and CA production. Serum contains many components, of which only a relatively small number have been identified and quantitated. One advantage of serum-free culture medium is that the soluble factors presented by the experimenter to the extracellular environment are both few in number and well defined. it is thus possible to explore systematically how each component affects the cells. A first step in studying the mechanisms by which the ingredients of N2 medium are able to maintain the long-term growth and differentiation of primary cultures of sympathetic neurons (in concert with nerve growth factor) is to determine the relative importance of each component in maintaining cell survival and CA production. Table $V$ shows the effects on survival and CA production of systematic changes in the N2 recipe. Removal of putrescine, selenium, and progesterone from the serum-free medium results in a 30\% decrease in cell survival, without affecting CA production on a per neuron basis. Varying the concentrations of the remaining components, insulin and transferrin, by two orders of magnitude, does not further adversely affect cell survival until the concentrations of insulin and transferrin fall to 0.5 and $1 \mu \mathrm{g} / \mathrm{ml}$, respectively. No effect on CA production per neuron is observed even at this point. At levels of insulin and transferrin below those shown, cell survival and CA production were highly variable. Insulin and transferrin thus appear to be the most important factors promoting neuronal survival in N2 medium.

The serum-free cultures discussed above and in the preceding sections were originally plated in serum-containing medium on a substrate of air-dried collagen and switched to serum-free medium on the first or second day after plating. The requirement for serum in the culture medium for initial cell attachment cannot be replaced by overnight preincubation of the collagen substrate with rat serum or by plating onto monolayers of paraformaldehyde-fixed heart cells

TABLE $V$

Dose response of survival and CA production to insulin and transferrin

Cell counts and CA production during metabolic labeling are shown for cultures maintained in the media indicated. "Complete N2" is $\mathrm{L} 15 / \mathrm{CO}_{2}$ supplemented with all five $\mathrm{N} 2$ ingredients. "Complete $R S^{\prime}$ " is $\mathrm{L} 15 / \mathrm{CO}_{2}$ supplemented with $5 \%$ rat serum. "Incomplete $\mathrm{N} 2$ " is $\mathrm{L} 15 / \mathrm{CO}_{2}$ supplemented only with insulin and transferrin at the indicated concentration in micrograms per milliliter.

\begin{tabular}{|c|c|c|c|c|c|}
\hline Medium & $\begin{array}{l}\text { Insulin } \\
(\mu \mathrm{g} / \mathrm{ml})\end{array}$ & $\begin{array}{c}\text { Transferrin } \\
(\mu \mathrm{g} / \mathrm{ml})\end{array}$ & $\begin{array}{l}\text { Neurons } \\
\text { per Dish }\end{array}$ & $\mathrm{CA} / \mathrm{N}$ (fmol) & $\begin{array}{l}\text { No. of } \\
\text { Cultures }\end{array}$ \\
\hline Complete N2 & 5 & 100 & $3420 \pm 210$ & $3.70 \pm 1.27$ & 2 \\
\hline Complete RS & & & $3901 \pm 1119$ & $3.00 \pm 0.84$ & 2 \\
\hline Incomplete N2 & 5 & 100 & 2400 & 3.22 & 1 \\
\hline $\begin{array}{l}\text { Insulin and } \\
\text { transferrin only }\end{array}$ & 0.5 & 100 & 2300 & 3.68 & 1 \\
\hline $\begin{array}{l}\text { Insulin and } \\
\text { transferrin only }\end{array}$ & 0.05 & 100 & 2630 & 4.04 & 1 \\
\hline $\begin{array}{l}\text { Insulin and } \\
\text { transferrin only }\end{array}$ & 5 & 10 & 2300 & 4.14 & 1 \\
\hline $\begin{array}{l}\text { Insulin and } \\
\text { transferrin only }\end{array}$ & 0.5 & 10 & 2080 & 3.25 & 1 \\
\hline $\begin{array}{l}\text { Insulin and } \\
\text { transferrin only }\end{array}$ & 0.05 & 10 & 2470 & 5.24 & 1 \\
\hline $\begin{array}{l}\text { Insulin and } \\
\text { transferrin only }\end{array}$ & 5 & 1 & 2220 & 3.51 & 1 \\
\hline $\begin{array}{l}\text { Insulin and } \\
\text { transferrin only }\end{array}$ & 0.5 & 1 & 1750 & 3.89 & 1 \\
\hline
\end{tabular}


(Hawrot, 1980). However, after the experiments described in the preceding sections were performed, it was found that neurons could be plated successfully in the absence of serum, on a substratum of freshly prepared extracellular matrix from cultured bovine endothelial cells (Gospodarowicz et al., 1980). Although cell survival is somewhat decreased under these conditions, CA production per neuron is within the range of that of serum-containing and N2 cultures plated on collagen film (Fig. 9). ACh production by serum-free cultures is not affected by plating on bovine endothelial cell extracellular matrix Thus, it is possible to further simplify culture conditions by eliminating exposure of the neurons to serum during plating.

\section{Discussion}

The data reported here show that sympathetic neurons are able to survive and maintain differentiated characteristics when cultured under serum-free conditions. Conventionally grown, serum-containing cultures were used as a standard of comparison.

Survival and CA metabolism. Survival and growth with and without serum supplementation, in terms of number of neurons per culture (Fig. 1A) and amount of protein per neuron, are similar. Thus, normalization of data per culture, per neuron, or per milligram of protein yields equivalent results. Similarities in values obtained in various assays of the two types of culture, therefore, cannot be explained by compensatory changes in neuronal protein content or cell numbers.

Several aspects of CA metabolism were measured biochemically: transmitter production during metabolic labeling, uptake and release of $\left[{ }^{3} \mathrm{H}\right] \mathrm{NE}$, and $\mathrm{TH}$ activity. The metabolic labeling technique employed assesses the net accumulation of NE, DA, and ACh (Patterson and Chun, 1977). The resultant measure of transmitter content depends on the combined anabolic and catabolic activities of living neurons. The similarity in CA production between serum-free and serum-containing cultures measured by this technique (Fig. 1B) reflects equivalence in the final outcome of the processes of synthesis, storage, turnover, release, and reuptake, and their regulation. In addition, several inferences can be drawn concerning specific aspects of CA metabolism in serum-free cultures. The reserpine sensitivity of $\mathrm{CA}$ (but not $\mathrm{ACh}$ ) production under both culture conditions (Table I) shows that accumulation of CA measured by metabolic labeling is dependent on transport into a storage compartment by a CA-specific mechanism. The similarity between serum-free and serum-containing cultures in the relative proportion of NE and DA production during metabolic labeling is presumably due to equivalent activity of dopamine $\beta$-hydroxylase, which converts DA to NE. TH activity was measured independently in cell extracts and was also found to be similar in both types of culture (Fig. 3).

$\mathrm{TH}$ activity in defined medium and serum-containing cultures of lacovitti et al. (1982) was also reported to be similar; however, dopamine $\beta$-hydroxylase activity was depressed in the serum-free cultures. The culture conditions used by lacovitti et al. (1982) differ from those in the present experiments in basal nutrient medium (a mixture of Dulbecco's Modified Eagle's medium (DME) and F12 rather than L15) and serum supplement (chick embryo extract and human placental serum, rather than homologous serum), and in the age of animals from which ganglia were explanted (fetal rather than neonatal), which could explain differences with results reported here. In addition, unlike the experiments reported here, those of lacovitti et al. (1982) used different basal media for serum-supplemented (Eagle's minimum essential medium) and serum-free (F12/DME) cultures, which may also have affected their results.

NE uptake and release were also assayed independently of the metabolic labeling technique. The similarity in the amount of $\left[{ }^{3} \mathrm{H}\right] \mathrm{NE}$ accumulated by both types of cultures indicates equivalent combined uptake and storage capacity. Release rates for stored radioactivity were also similar (Fig. 4). The spontaneous release rates show that CA stores in both types of cultures are equally stable. The more rapid release rates induced by depolarization with $54 \mathrm{~mm}$ potassium suggest that the mechanisms for synaptic release function cquivalently in both types of cultures.

ACh production. The only difference observed between serumcontaining and serum-free cultures by metabolic labeling is the low level of ACh production in serum-free cultures. The serum-free medium itself does not inhibit development of ACh production capacity, since serum-containing cultures supplemented with N2 ingredients, and serum-free cultures supplemented with cholinergic inducing factor from heart cell conditioned medium, are able to produce as much ACh as serum-containing controls (Fig. 2). Thus, the low ACh production by L15N2 cultures appears to be due to the absence of rat serum, and in fact, rat serum does contain cholinergic inducing activity (discussed in Wolinsky and Patterson, 1985a).

It is also clear that, despite the presence of cholinergic inducing activity, serum is not essential to produce either the cholinergic or the noradrenergic phenotype, since neurons can express both of these phenotypes under serum-free conditions: cholinergic, with SFCM supplementation, and noradrenergic, in unsupplemented L15N2. The response to cholinergic inducing activity under serumfree conditions has the same features as in conventional cultures: elevation of ACh production is accompanied by decreased CA production and a fall in TH specific activity (Fig. 3).

Morphology. The morphology of serum-free cultures at both the light (Fig. 5) and electron microscopic (Fig. 6) levels appears superficially similar. In contrast with the results of lacovitti et al. (1982), synapses and varicosities containing numerous small granular vesicles were frequently observed in cultures grown without serum. However, the distribution of synaptic vesicle types in serum-free cultures was found to deviate significantly from that expected. Potter et al. (1980) have established a positive correlation between the degree of noradrenergic function assayed physiologically and the frequency of small granular vesicles in permanganate-fixed microcultures consisting of individual neurons. These results lead to the

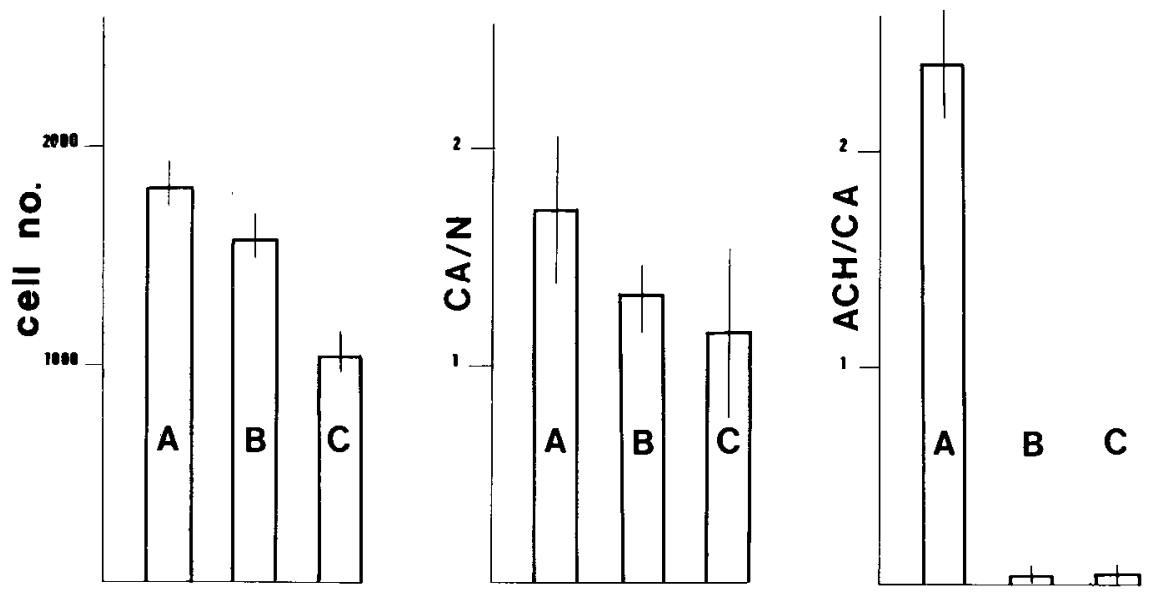

Figure 9. Effect of extracellular matrix on survival and neurotransmitter production. The left pane/ shows the number of neurons per culture in dishes coated with bovine endothelial cell matrix as observed with phase contrast optics (mean $\pm \mathrm{SE}$ for three cultures). The center panel shows CA production during metabolic labeling in femtomoles per neuron (mean $\pm \mathrm{SE}$ for three cultures). The right panel shows the ratio of ACh to CA production during metabolic labeling (mean $\pm \mathrm{SE}$ for three cultures). $A$, Cultures plated and maintained entirely in serum-containing medium for the entire culture period. Survival and CA production in these cultures was comparable to or better than that of sister cultures plated on collagen without extracellular matrix from bovine endothelial cells. $B$, Cultures plated overnight in serum-containing medium, then switched to L15N2 medium for the remainder of the culture period. C, Cultures plated in L15N2 medium for the entire culture period. 
prediction that serum-free cultures, which produce $\mathrm{CA}$ and little $\mathrm{ACh}$, would contain mostly small granular vesicles and relatively few clear vesicles. The data indicate, however, that serum-free cultures contain only $23 \%$ small granular vesicles, compared to $40 \%$ in serumcontaining cultures (Fig. 8). This result can be examined from two different viewpoints: the lower small granular vesicle frequency of serum-free cultures may be attributed to either a paucity of densecored vesicles or to an overabundance of clear vesicles.

The biochernical evidence presented here suggests that CA storage capacity is equal in both types of cultures. If the absolute number of small granular vesicles per neuron is lower in serum-free cultures, then CA must be stored elsewhere. It is unlikely that CA is stored extravesicularly in serum-free cultures because of the reserpine sensitivity of CA production, and because of the presence of cytoplasmic degradative enzymes, such as monoamine oxidase, which would render such stores unstable. Permanganate fixation after preincubation with 5-OHDA does not result in formation of precipitate in other cellular compartments, as has been observed in dopaminergic neurons of rat substantia nigra (Hattori et al., 1979). Thus, it is possible that some of the clear vesicles contain CA in a novel form of storage complex which does not form a granular precipitate with potassium permanganate.

The absolute number of transmitter storage vesicles per neuron in these cultures is unknown. It is possible that serum-free cultures contain twice as many vesicles per neuron as serum-containing cultures. If this is the case, then despite the low small granular vesicle frequency of serum-free cultures, serum-free and serumcontaining cultures would have equal absolute numbers of smail granular vosicles and, thus, cqual CA storage capacity per neuron. According to this hypothesis, the vesicles comprising the population increase would have the clear morphology usually associated with ACh storage. In this case, the clear morphology would be associated with empty vesicles, containing no stored transmitter. Alternatively, some clear vesicles in serum-free cultures may store unidentified transmitter substances.

The dissociation of values for small granular vesicle frequency and ratio of ACh to CA production in serum-free cultures may be a significant aspect of their transmitter phenotype. The low small granular vesicle frequency of serum-free cultures after 1 month in vitro is probably a change from the percentage of dense-cored vesicles present at the time of plating, since cultures grown in serum contain greater than $80 \%$ small granular vesicles at 4 days in vitro (Landis, 1980). Future determination of the effects of chronic depolarization and of heart cell conditioned medium on vesicle distribution in serum-free cultures may help explain the significance of the high frequency of clear vesicles. Preliminary data (not shown) on depolarized serum-free cultures indicate that high potassium medium can significantly decrease the frequency of clear vesicles. This suggests that a large proportion of clear vesicles in nondepolarized serumfree cultures are associated with incomplete cholinergic function, since depolarization acts primarily by blocking cholinergic development. If this is the case, then synthesis of ACh storage vesicles and production of the transmitter itself would appear to be dissociable in cultures, with intrinsic information specifying vesicle synthesis, and exterior stimuli, such as rat serum or SFCM, controlling transmitter synthesis. It is also possible that the clear vesicles are not associated with storage of any particular transmitter, but are produced in excess over the requirement for storage of CA. Either chronic depolarization or exposure to rat serum may result in recoupling the production of vesicles to production of transmitter.

Simplification of the culture environment. The ideal culture environment for studying external influences on neuronal differentiation is one which is fully permissive for the expression of any phenotypic feature but which itself does not instruct developmental decisions. In order to evaluate potential effects of the culture environment on developmental choices, it would also be convenient for the culture system to consist of a limited number of defined components, so that each can be tested systematically. The methods for serum-free culture of sympathetic neurons described in this report are attempts to meet these criteria. Replacement of rat serum with N2 ingredients removes a potent cholinergic inducing stimulus from the culture environment. Replacement of serum with defined ingredients also renders the culture environment more uniform from plating to plating

The small number of ingredients in the N2 formulation of Bottenstein and Sato (1979) makes it easy to assess the role each plays in maintaining neuronal growth. Putrescine, selenium, and progesterone are in fact not essential, and the levels of transferrin and insulin required are considerably lower than those originally specified (Table $\mathrm{V}$ ). This reduces the number of medium additives to be scrutinized for developmental influences to two. Transferrin has not been observed to affect any aspects of neuronal phenotype studied so far. Insulin, however, has been determined to increase electrical coupling between neurons and is further discussed in Wolinsky and Patterson (1985b).

In addition to soluble components, the culture substratum must be considered. Neurons plated on dried collagen film require overnight exposure to serum-containing medium for attachment and survival, whereas serum is not required to establish cultures on extracellular matrix from bovine endothelial cells (Fig. 9). The acidic extract of rat tail tendons used to prepare the collagen film contains other proteins besides collagen and thus is not a well defined material. Some of these contaminants are probably required by neuronal cultures, since purified collagen is a poor culture substrate. Bovine endothelial cell matrix is in this respect no improvement over collagen film, since its composition is not fully determined either. In addition, since the bovine endothelial cells are maintained in medium containing fetal calf and calf sera, some adsorbed serum components are probably retained by the matrix after cell lysis and washing with buffer. The possibility that this matrix exerts influence on some aspect of the neuronal phenotype not studied here has not been excluded. This matrix does affect the pattern of collagen secretion expressed by bovine endothelial cells themsclves (Tseng et al., 1983). However, the use of bovine endothelial cell matrix allows full control over the soluble additions to the culture environment and does not itself influence transmitter choice. It may also be possible in the future to gain better control of the substratum by systematically testing known components of extracellular matrix such as laminin and proteoglycans to determine which type of molecule can substitute for serum during initial neuronal attachment.

Phenotype of sympathetic neurons cultured under serum-free conditions. The L15N2 formulation yields cultures which are indistinguishable from serum-supplemented cultures by a variety of assays; however, they do possess some unexpected properties, such as their synaptic vesicle profile and electrical coupling (Higgins and Burton, 1982; Wolinsky and Patterson, 1985b). Serum-free cultures have noradrenergic transmitter status, as do serum-containing cultures maintained in depolarizing medium (Walicke et al., 1977). Increased activity may be thought of as stabilizing the pre-existing noradrenergic phenotype already expressed by the neonatal principal neurons of the superior cervical ganglion prior to plating (Walicke et al., 1977; data summarized by Landis, 1980). Does this interpretation also apply to serum-free noradrenergic cultures? In some platings, nondepolarized, serum-free cultures were distinguishable from depolarized, serum-containing cultures by a small but significantly greater amount of ACh production. This difference could be due to their brief exposure to the cholinergic influence of serum at the time of plating, without subsequent stabilization of noradrenergic properties by high potassium medium. Chronic depolarization, however, eliminated this difference. Chronic depolarization of serum-free cultures also reduced the effects of concomitant SFCM treatment (Table IV). Thus, sympathetic neurons are capable of responding to chronic depolarization under serum-free conditions. These data suggest that the mechanisms by which chronic depolarization and serum removal produce the noradrenergic phenotype are different. This idea is consistent with the hypothesis that chronically depolarized, serum-containing cultures are able to resist the cholinergic 
influence of serum due to stabilization of their pre-existing noradrenergic phenotype by electrical activity, whereas serum-free cultures merely lack exposure to cholinergic inducing activity.

According to the interpretation above, serum-free cultures retain plasticity with respect to transmitter choice while maintaining noradrenergic transmitter status. However, one experimental result does not seem fully consistent with this view. When heart cell conditioned medium is applied midway through the culture period, the response of serum-free cultures is poor compared to that of nondepolarized, serum-containing cultures (Table IV). The interpretation of this experiment is complicated, however, by the fact that the transmitter status at the time of SFCM treatment probably affects the final level of cholinergic function attained. Serum-containing cultures have been exposed to cholinergic inducing activity in rat serum during the first half of the culture period and have presumably achieved a level of cholinergic function significantly higher than that of serumfree cultures of the same age. The level of cholinergic function attained in response to subsequent SFCM treatment may be enhanced by previous exposure to serum cholinergic inducing activity. Thus, poor response to SFCM by serum-free cultures in this paradigm may be due to their lower level of cholinergic function compared to serum-containing cultures at the onset of SFCM treatment, rather than to loss of plasticity.

This difference between the two types of noradrenergic cultures suggests an interpretation of the transmitter status of serum-free cultures: neurons grown under serum-free conditions may be considered to be suspended at the point in the process of transmitter determination which they had reached at the time of dissociation from neonatal rat superior cervical ganglion. Neonatal superior cervical ganglion neurons, like serum-free cultures, are noradrenergic, but plastic. Later in development, as shown for sweat gland innervation by Landis and Keefe (1983), some of these neurons gradually become cholinergic, perhaps in response to factors secreted by their targets. Cultured dual-function neurons are considered to be in a state analogous to that of sympathetic neurons undergoing this transition in vivo. When neonatal sympathetic neurons are maintained in conventional cultures in the presence of rat serum, they are exposed to modest levels of cholinergic inducing activity present in the serum and develop dual-function properties. Chronic depolarization blocks the cholinergic effect of rat serum as a result of stabilization of the noradrenergic phenotype present at the time of plating. Without high potassium or rat serum in the culture medium, the culture environment is neutral with respect to transmitter choice. Neurons maintained under these conditions remain static in their degree of transmitter determination, neither developing cholinergic characteristics nor becoming fixed in the noradrenergic state. Perhaps neurons cultured under serum-free conditions may be considered analogous to that of developing sympathetic neurons in vivo which have not yet been exposed to cholinergic influences or yet stabilized in the noradrenergic state by electrical activity.

\section{References}

Ahmed, Z., P. S. Walker, and R. E. Fellows (1983) Properties of neurons from dissociated fetal rat brain in serum-free culture. J. Neurosci. 3: 24482462.

Bader, C. R., D. Bertrand, E. Dupin, and A. C. Kato (1983) Development of electrical membrane properties in cultured avian neural crest. Nature 305 : 808-810.

Barnes, D., and G. H. Sato (1980) Serum-free cell culture: A unifying approach. Cell 22: 649-655.

Bocchini, $V_{.}$, and P. U. Angeletti (1969) The nerve growth factor: Purification of a 30,000-molecular weight protein. Proc. Natl. Acad. Sci. U. S. A. 64. 787

Bottenstein, J. E., and G. H. Sato (1979) Growth of a rat neuroblastoma line in serum-free supplemented medium. Proc. Natl. Acad. Sci. U. S. A. 76: 514-517.

Bottenstein, J. E., S. D. Skaper, S. S. Varon, and G. H. Sato (1980) Selective survival of neurons from chick embryo sensory ganglionic dissociates using serum-free supplemented medium. Exp. Cell Res. 125: 183-190.

Darfler, F. J., R. J. Hughes, and P. A. Insel (1981) Characterization of serum- induced alterations in the cyclic AMP pathway in S49 lymphoma cells. J. Biol. Chem. 256: 8422-8428.

Dibner, M. D., and P. A. Insel (1981) Serum catecholamines desensitize betaadrenergic receptors of cultured C6 glioma cells. J. Biol. Chem. 256: 7343-7346.

di Porzio, U., M. -C. Daguet, J. Glowinsky, and A. Prochiantz (1980) Effect of striatal cells on in vitro maturation of mesencephalic dopamincrgic neurons grown in serum-free conditions. Nature 288: 370-373.

Freschi, J. (1982) Effect of serum-free medium on growth and differentiation of sympathetic neurons in culture. Brain Res. 256: 455-464.

Fukada, K. (1980) Hormonal control of neurotransmitter choice in sympathetic neuron cultures. Nature 287: 553-555.

Furshpan, E. J., P. R. MacLeish, P. H. O'Lague, and D. D. Potter (1976) Chemical transmission between rat sympathetic neurons and cardiac myocytes developing in microcultures: Evidence for cholinergic, adrenergic, and dual-function neurons. Proc. Natl. Acad. Sci. U. S. A. 73: 42254229.

Gospodarowicz, D., D. Delgado, and I. Vlodavsky (1980) Permissive effect of the extracellular matrix on cell proliferation in vitro. Proc. Natl. Acad. Sci. U. S. A. 77: 4094-4098.

Ham, R. G. (1981) Survival and growth requirement of nontransformed cells In Handbook of Experimental Pharmacology, R. Baserga, ed., Vol. 57, pp. 13-88, Springer-Verlag, New York.

Hattori, T., P. L. McGeer, and E. G. McGeer (1979) Dendro-axonic neurotransmission. II. Morphological sites for the synthesis, binding, and release of neurotransmitters in dopaminergic dendrites in the substantia nigra and cholinergic dendrites in the neostriatum. Brain Res. 170: 71-83.

Hawrot, E. (1980) Cultured sympathetic neurons: Effects of cell-derived and synthetic substrata on survival and development. Dev. Biol. 74: 136-151.

Hawrot, E., and P. H. Patterson (1979) Long-term culture of dissociated sympathetic neurons. Methods Enzymol. 58: 574-584.

Hendry, I. A., and L. L. Iversen (1971) Effect of nerve growth factor and its antiserum on tyrosine hydroxylase activity in mouse superior cervical sympathetic ganglion. Brain Res. 29: 159-162.

Higgins, D., and H. Burton (1982) Electrotonic synapses are formed by fetal rat sympathetic neurons maintained in a chemically-defined medium. Neuroscience 7: 2241-2253.

Hokfelt, T. (1968) In vitro studies on central and peripheral monoamine neurons at the ultrastructural level. Z. Zellforsch. 9: 1-74.

lacovitti, L., T. H. Joh, D. H. Park, and R. P. Bunge (1981) Dual expression of neurotransmitter synthesis in cultured autonomic neurons. J. Neurosci. 1: $685-690$.

lacovitti, L., M. I. Johnson, T. H. Joh, and R. P. Bunge (1982) Biochemical and morphological characterization of sympathetic neurons grown in a chemically-defined medium. Neuroscience 7: 2225-2239.

Iversen, L. (1967) The Uptake and Storage of Noradrenaline in Sympathetic Nerves, Cambridge University Press, Cambridge, England.

Landis, S. C. (1980) Developmental changes in the neurotransmitter properties of dissociated sympathetic neurons: A cytochemical study of the effects of medium. Dev. Biol. 77: 349-361.

Landis, S. C., and D. Kecfe (1983) Evidence for neurotransmitter plasticity in vivo: Developmental changes in properties of cholinergic sympathetic neurons. Dev. Biol. 98: 349-372.

Mains, R. E., and P. H. Patterson (1973) Primary cultures of dissociated sympathetic neurons. I. Establishment of long-term growth in culture and studies of differentiated properties. J. Cell Biol. 59: 329-345.

Messer, A., J. E. Mazurkiewicz, and P. Maskin (1981) Growth of dissociated rat cerebellar cells using serum-free supplemented media and varied transferrin concentrations. Cell. Mol. Neurobiol. 1: 99-114.

Mohamed, S. N. W., R. Holmes, and C. R. Hartzell (1983) A serum-free, chemically defined medium for function and growth of primary neonatal rat heart cell culturcs. In Vitro 19: 471-478.

Morrison, R. S., and J. DeVellis (1981) Growth of purified astrocytes in a chemically defined medium. Proc. Natl. Acad. Sci. U. S. A. 78: 72057209

Patterson, P. H. (1978) Environmental determination of autonomic neurotransmitter functions. Annu. Rev. Neurosci. 1: 1-17.

Patterson, P. H., and L. L. Y. Chun (1977) The induction of acetylcholine synthesis in primary cultures of dissociated rat sympathetic neurons. I. Effects of conditioned medium. Dev. Biol. 56: 263-280.

Patterson, P. H., L. F. Reichardt, and L. L. Y. Chun (1976) Biochemical studies on the development of primary sympathetic neurons in cell culture. Cold Spring Harbor Symp. Quant. Biol. 40: 389-397.

Potter, D. D., S. C. Landis, and E. J. Furshpan (1980) Dual function during 
development of rat sympathetic neurons in culture. J. Exp. Biol. 89: 5771.

Raff, M. C., R. H. Miller, and M. Noble (1983) A glial progenitor cell that develops in vitro into an astrocyte or an oligodendrocyte depending on culture medium. Nature 303: 390-396.

Richardson, K. C. (1966) Electron microscope identification of autonomic nerve endings. Nalure 210: 756

Savage, C. R., Jr., and S. J. Cohen (1972) Epidermal growth factor and a new derivative: Rapid isolation and biological and chemical characterization. J. Biol. Chem. 247: 7609-7611.

Sweadner, K. J. (1983) Post-translational modification and evoked release of two large surface proteins of sympathetic neurons. J. Neurosci. 3: 25042517.

Swerts, J. -P., A. Le Van Thai, A. Vigny, and M. J. Weber (1983) Regulation of enzymes responsible for neurotransmitter synthesis and degradation in cultured rat sympathetic neurons. I. Effects of muscle-conditioned medium. Dev. Biol. 100: 1-11.

Tranzer, J. P., and H. Thoenen (1967) Electron microscopic localization of 5 hydroxydopamine (3,4,5-trihydroxy-phenylethylamine), a new "false" sympathetic transmitter. Experientia 23: 743-745.

Tseng, S. C. G., N. Savion, D. Gospodarowicz, and R. Stern (1983) Modulation of collagen synthesis by a growth factor and by extracellular matrix: Comparison of cellular response to two different stimuli. J. Cell Biol. 97: 803-809.

Wakade, A. R., D. Edgar, and H. Thoenen (1982) Substrate requirements and media supplements necessary for the long-term survival of chick sympathetic and sensory neurons cultured without serum. Exp. Cell Res. 140: $71-78$.
Walicke, P. A., and P. H. Patterson (1981a) On the role of cyclic nucleotides in the transmitter choice made by cultured sympathetic neurons. $\mathrm{J}$. Neurosci. 1: 333-342.

Walicke, P. A., and P. H. Patterson (1981b) On the role of $\mathrm{Ca}^{2+}$ in the transmitter choice made by cultured sympathetic neurons. J. Neurosci. 1: 343-350.

Walicke, P. A., R. B. Campenot, and P. II. Patterson (1977) Determination of transmitter function by neuronal activity. Proc. Natl. Acad. Sci. U. S. A. 74: $5767-5771$

Wallace, L. H., and L. M. Partlow (1978) A sensitive microassay for protein in cells cultured on collagen. Anal. Biochem. 87: 1-10.

Weber, M. J. (1981) A diffusible factor responsible for the determination of cholinergic functions in cultured sympathetic neurons: Partial purification and characterization. J. Biol. Chem. 256: 3447-3453.

Wolinsky, E., and P. H. Patterson (1983) Tyrosine hydroxylase activity decreases with induction of cholinergic properties in cultured sympathetic neurons. J. Neurosci. 3: 1495-1500.

Wolinsky, E., S. C. Landis, P. H. Patterson, and A. Willard (1983) Influence of serum on cultured sympathetic neurons. Soc. Neurosci. Abstr. 9: 4.

Wolinsky, E. J., and P. H. Patterson (1985a) Rat serum contains a developmentally regulated cholinergic inducing activity. J. Neurosci. 5: 1509-1512. Wolinsky, E. J., and P. H. Patterson (1985b) Insulin promotes electrical coupling between cultured sympathetic neurons. J. Neurosci., in press.

Zeevalk, G. D., L. L. Cedarqvist, and K. M. Lyser (1982) The ultrastructure of human fetal sympathetic ganglion cells in serum-free medium. Dev. Brain Res. 4: 248-252

Zillcr, C., E. Dupin, P. Brazeau, D. Paulin, and N. M. Le Douarin (1983) Early segregation of a neuronal precursor cell line in the neural crest as revealed by culture in a chemically defined medium. Cell $32: 627-638$. 